\title{
Os ciganos e a escola: encontro interétnico, fronteiras e autoatribuição no Acampamento Sol ${ }^{1}$
}

\section{Gypsies and school: inter-ethnic meeting, boundaries and self-attribution in the Sun Camp}

\author{
Ana Kátia Pereira PINTO² \\ Ivone Martins de OLIVEIRA ${ }^{3}$
}

\begin{abstract}
Resumo
O estreitamento do contato interétnico, a fixação e a obrigatoriedade da frequência à escola por crianças e jovens, têm alterado as relaçôes entre ciganos e escola. Este artigo se propôs discutir os significados da escola para ciganos adultos que se fixaram em um município do Estado do Espírito Santo. A etnografia foi o caminho investigativo que norteou a pesquisa e os colaboradores pertencem, majoritariamente, a um único grupo familiar. A análise concentrou-se em dois posicionamentos desses colaboradores: um ressalta que "a escola é o fim do cigano" e o outro afirma que "a escola é uma luz no caminho do cigano".
\end{abstract}

Palavras-chave: Ciganos. Escola. Encontro interétnico.
Abstract

The narrow inter-ethnic contact, the settlement and the children and young adults 'obligation to attend the school, has changed the relations between gypsies and the school. This article has proposed to discuss meanings of the school for adult gypsies who set up camp in a city in the state of Espírito Santo. The ethnography was the investigative path that oriented this research and the collaborators mostly belong to a single familiar group. The analysis is centered on two opinions among the research collaborators: one highlighting that "schools are the end of the gypsy people" and the other that affirms that "schools are the light crossing the gypsies' path".

Keywords: Gypsies. School. Inter-ethnic meetings.

1 Este texto é parte de uma tese de doutorado financiada pela Fundação de Amparo à Pesquisa e Inovação do Espírito Santo (FAPES), que teve como objetivo compreender o que a escola significa para ciganos de um acampamento localizado em um município do estado do Espírito Santo.

2 Doutora em Educação pela Universidade Federal do Espírito Santo (UFES). Fonoaudióloga na Prefeitura Municipal de Vila Velha. Lattes: http://lattes.cnpq.br/7171605613021112. Orcid: https://orcid. org/0000-0001-9945-0922. E-mail: anakatiapp@gmail.com

3 Doutora em Educação e professora titular da Universidade Federal do Espírito Santo (UFES). Lattes: http://lattes.cnpq.br/4371604685952253. Orcid: https://orcid.org/0000-0002-5948-4797. E-mail: ivone.mo@terra.com.br 


\section{Introdução}

Durante muito tempo, as andanças dos ciganos pelo mundo fizeram com que a relaçáo entre eles e a escola fosse marcada por intensos conflitos. Por não se encaixarem em vários padróes estabelecidos pela sociedade majoritária, tiveram o direito de acesso a serviços públicos - entre eles a escola - negado. Porém, a atualidade tem indicado outros contornos desenhando as paisagens das zonas fronteiriças. A fixaçáo da moradia e a ida das crianças para a escola propiciaram transformaçôes significativas na organização social de muitos grupos ciganos e, consequentemente, no diálogo com a escola. Tais mudanças sinalizam a porosidade, a permeabilidade das fronteiras: o dentro e o fora em fluxo, em constantes movimentos de negociações.

É nesse contexto que este artigo se propóe discutir os significados da escola para ciganos adultos que se fixaram em um acampamento localizado em município do Estado do Espírito Santo. Mesmo em um período em que as políticas educacionais desenvolvidas pelo Ministério da Educação se voltam à expansão e ampliação do nível de escolaridade da população (BRASIL, 2001) e à universalização da educação básica (BRASIL, 2014), os parcos estudos sobre a escolarização de ciganos no Brasil têm apontado desafios para a inserção desse grupo no sistema educacional: o restrito acesso desse povo à escola; as dificuldades enfrentadas por membros dessa etnia ao frequentarem essa instituição; certa resistência dos adultos em se matricularem na escola; falta de incentivo dos pais para seus filhos mais velhos darem continuidade aos estudos (FERRARI, 2010; BAREICHA, 2013; MULLER, 2014). Por outro lado, parte significativa dos ciganos adultos do acampamento que colaborou com esta investigação manifestou o desejo de ir para a escola, intrigando-nos sobre os motivos que os teriam levado a essa mudança.

Assim, desenvolvemos uma investigação que se inseriu no campo da pesquisa qualitativa em educação, orientada por uma perspectiva etnográfica. Para Malinowski (1984), a etnografia pode ser entendida como um empreendimento no qual cabe ao pesquisador a descrição do ser humano em sua própria localidade, por meio da ida a campo e da observação participante, procedimento de pesquisa que possibilita ao pesquisador compartilhar significados e sentimentos dos e com os outros. Para Malinowski, essa imersão no campo decorre do fato de que, na etnografia, o autor é, simultaneamente, o seu próprio cronista e historiador, ele está envolvido com pessoas que apresentam modos complexos e diversos de ser e de estar no mundo e não com documentos frios e inertes, como pode ocorrer quando o pesquisador analisa dados coletados por outras pessoas. 
Geertz (2008), afirma que a prática etnográfica demanda uma descrição densa. Quando o pesquisador descreve o que observa, deve ter em mente que o objeto da etnografia é uma intrincada teia de estruturas significantes que deve ser interpretada. $\mathrm{O}$ que o etnógrafo encontra durante a pesquisa de campo é "[...] uma multiplicidade de estruturas conceptuais complexas, muitas delas sobrepostas ou amarradas umas às outras, que são simultaneamente estranhas, irregulares e inexplícitas, e que ele tem que, de alguma forma, primeiro apreender e depois apresentar" (GEERTZ, 2008, p. 7).

A pesquisa do tipo etnográfico requer longo tempo no campo para a compreensão dos significados que perpassam determinado aspecto de sua organização social. Disso decorre a participação em eventos significativos para o grupo; o que gera a proximidade, trazendo uma familiaridade enriquecedora, mas também um desafio: estranhar o familiar. Essa é uma tarefa difícil, como destaca Velho (2003). No contato prolongado com os colaboradores do estudo, o esforço de estranhamento do que vai se tornando familiar envolve desafios como: escapar do olhar tendencioso, preconcebido; registrar o que se observa do modo menos etnocêntrico possível.

Logo, anotar a construção de uma "leitura de mundo" não é tarefa fácil, visto que o pesquisador tem seu olhar atravessado por seus próprios filtros identitários. Portanto, apreender a visão de mundo do outro - diferente, intrigante - implica a revisão constante e cuidadosa das escolhas feitas para o registro e o modo de registrar. Assim, a construção e a reconstrução metodológica deste estudo orientaram-se por uma atenção cuidadosa ao estranhamento da familiaridade, procedimento fundamental para que a pesquisa se desenvolvesse.

O contato e a familiaridade com os colaboradores deste estudo foi se estabelecendo durante alguns anos de convivência entre pesquisadoras e ciganos do acampamento que denominamos Sol. Com o passar dos anos, a confiança do grupo em relação a nós aumentou significativamente, propiciando aberturas para o compartilhamento de questôes cada vez mais íntimas, tornando mais nítidas as possibilidades e limitaçóes do estudo.

No desenvolvimento da pesquisa, constatamos que a composição de um acampamento cigano é muito dinâmica. Nas andanças dos ciganos, um acampamento pode abarcar ora muitas ora poucas famílias, cujos componentes, de modo geral, pertencem a diferentes geraçóes de um mesmo grupo familiar. Esse foi o caso dos colaboradores deste estudo. No período da pesquisa, compunha o núcleo do acampamento o Sr. Valdir, sua esposa, Lena, seus filhos, noras e netos. Os três filhos do casal eram casados com náo ciganas que, com o casamento, passaram a adotar o modo de vida cigano. A única filha foi entregue à adoção ainda quando criança e educada em ambiente não cigano, por isso náo compôs este estudo. 
Desde o nosso primeiro contato com o grupo, em 2008, até 2016, o Sr. Valdir e sua família mudaram-se muitas vezes. A partir da posse de uma propriedade, o processo de fixação ocorreu e a configuraçáo habitual do acampamento ${ }^{4}$ começou a mudar. As barracas deram lugar às casas de alvenaria; alguns construíram garagens para os carros; o espaço denominado barracão mudou de lugar; foi construído um banheiro coletivo, com chuveiro elétrico, vaso sanitário e pia, substituindo os locais improvisados anteriormente ao lado das barracas. Mesmo com essas mudanças, os ciganos continuavam chamando o espaço de "acampamento", assim como "barracas" as casas de alvenaria. Nesse encontro interétnico, questionamos: como vão se (re)configuando as fronteiras entre ciganos e não ciganos para esse grupo? Como compreender os significados que perpassam a escola em meio a essas transformaçôes? Essas são questôes que abordaremos a seguir.

Considerando a necessidade de um longo período no campo para apreender os significados atribuídos pelos colaboradores do estudo à escola, esta pesquisa ocorreu entre os anos de 2014 e 2017 . Um vínculo estabelecido entre uma das pesquisadoras e os ciganos do acampamento, principalmente algumas mulheres, favoreceu a decisão do grupo de participar do estudo. Inicialmente, como parte dos procedimentos de recolha de informaçóes, pensou-se na produção de um documentário, com a participação dos ciganos. Entretanto, diante das dificuldades encontradas com esse recurso, optou-se pela escuta dos ciganos adultos, em diferentes situaçóes e períodos de tempo. Assim, as informaçóes para a investigação foram recolhidas a partir de conversas informais com ciganas e ciganos, durante visitas sistemáticas ao acampamento, participação em almoços, lanches e festas. $\mathrm{O}$ registro das informaçóes recolhidas foi feito por meio de diário de campo e de fotografias.

Os vínculos criados com os ciganos abriram caminhos para as rememoraçóes, as confidências e, possivelmente, algumas reelaboraçóes. Diante dos objetivos deste texto, trazemos para o debate depoimentos que expressam dois posicionamentos radicalmente distintos sobre a escola, os quais são analisados a partir das contribuiçóes de autores como Cuche (1999), Barth (2011) e Bourdieu (1989; 2007).

4 Barracas dispostas lado a lado, mas sempre com a abertura frontal direcionada de tal modo que não fique de frente para outra barraca. No centro, um círculo de cimento, com estacas nas laterais e um teto enfeitado com fitas coloridas, por eles chamado de "barracão", lugar onde são realizadas as festas. 


\section{A cultura na perspectiva antropológica e a permeabilidade das fronteiras}

Conforme aponta Geertz (2008), no desenrolar da evolução humana, distintamente da vida animalesca, o homem se tornou um animal que fabrica instrumentos, altera as condiçóes naturais, comunica-se por meio da linguagem e cria símbolos. Em outras palavras, produz cultura, uma trama simbólica provida de significados que são transmitidos e recebidos, tecendo e orientando as existências humanas.

Abordando as diferenças entre os povos para além de aspectos biológicos, Cuche (1999) discorre sobre a cultura como um processo histórico e social, em que o contato e as relaçóes entre grupos distintos ocorrem em contextos de hierarquia que reproduzem as tensóes da sociedade de modo geral, uma vez que "[...] a cultura nasce de relaçóes sociais que são sempre desiguais" (CUCHE, 1999, p. 143).

$\mathrm{O}$ autor destaca que a questão hierárquica não significa superioridade entre um grupo cultural e outro e nem tampouco que uma cultura dominada seja alienada no processo de contato. Nessa relação, ambos podem mudar, ainda que o grupo dominante tenha mais condiçóes de imposição. Para Cuche (1999, p. 144), “[...] os grupos socialmente dominados não são desprovidos de recursos culturais próprios e sobretudo da capacidade de reinterpretar as produçóes culturais que lhes são impostas, em maior ou menor grau”, podendo produzir recriaçóes e renovações.

Sob esse prisma, este estudo compreende a cultura em uma perspectiva de transiçáo, na qual os conhecimentos circulam continuamente, produzindo-a e reproduzindo-a de acordo com as demandas do grupo, em diferentes momentos históricos. Assim, conhecer os sistemas simbólicos requer a compreensão das construçóes que determinado povo faz de suas vidas, o que implica a busca pelo conhecimento da "[...] fórmula que eles usam para definir o que lhes acontece" (GEERTZ, 2008, p. 11), já que é o conhecimento dessa trama simbólica que nos indica a leitura de mundo que os membros de determinado grupo produzem, realizam, praticam, atualizam.

Nessa acepção, conhecer os significados que os ciganos atribuem às suas ações para demarcar suas fronteiras é o ponto de partida para o alcance dos objetivos aqui propostos. Alcançá-los implica a desconstrução de olhares preconcebidos para a identificação dos símbolos escolhidos por eles para as demarcaçóes fronteiriças, assim como as (re)significaçóes e (re)elaboraçóes que fazem, a fim de sustentar a continuidade de um modo de vida em uma sociedade habitualmente inóspita. 
Geograficamente, as fronteiras são os limites que demarcam, por exemplo, a divisa entre duas ou mais naçóes. Com frequência, o termo é empregado para designar as zonas geopolíticas de possíveis disputas de poder. Sua função é quase paradoxal, já que serve tanto para separar, ao demarcar os extremos dos territórios, quanto para unificá-los, como linha unidimensional. Ao mesmo tempo que protegem (politicamente), representam a autonomia e a soberania. Por outro lado, estudiosos da área das Ciências Sociais têm utilizado o termo "fronteira" como dispositivo para a problematização de várias temáticas. Entre eles, está Fredrik Barth (2011), que aborda o tema fronteiras como uma questão social, mais que territorial.

$\mathrm{O}$ autor afirma que, de modo geral, o raciocínio antropológico parte do pressuposto de que a variação cultural não é contínua, ou seja: haveria agregaçóes humanas que, em essência, "[...] compartilham uma cultura comum, e diferenças interligadas que distinguiriam cada uma dessas culturas, quando analisadas separadamente de todas as outras" (BARTH, 2011, p. 187). Para Barth, tal pensamento prejudicou o estudo de alguns grupos étnicos, pois promoveu muita atenção às diferenças entre as culturas e os vínculos históricos estabelecidos e um olhar restrito ao modo como tais grupos se constituem e à natureza de suas fronteiras. Foi exatamente nesses aspectos pouco abordados que o autor concentrou suas reflexóes e estudo.

Segundo Barth (2011), a hipótese de que tribos e povos mantêm suas culturas diversas a partir do isolamento e afastamento de seus vizinhos é ingênua. As diferenças culturais podem permanecer apesar do contato interétnico e da interdependência dos grupos, visto que a interação não ocasiona o desaparecimento de um grupo étnico devido às mudanças ou aculturação. $\mathrm{O}$ autor entende os grupos étnicos como uma forma de organização social e inscreve a característica da autoatribuição ou da atribuição por outros como uma categoria étnica.

Uma atribuição categórica é uma atribuição étnica quando classifica uma pessoa em termos de sua identidade básica mais geral, presumivelmente determinada por sua origem e seu meio ambiente. Na medida em que os atores usam identidades étnicas para categorizar a si mesmos e outros, com objetivos de interação, eles formam grupos étnicos neste sentido, organizacional. É importante reconhecer que, embora as categorias étnicas tomem em consideração as diferenças culturais, não podemos deduzir disso uma simples relação de um para um entre as unidades étnicas e as semelhanças e diferenças culturais. As características que são levadas em consideração não são a soma das diferenças 'objetivas', mas somente aquelas que os próprios atores consideram significantes (BARTH, 2011, p. 194). 
$\mathrm{Na}$ abordagem barthiana, os grupos étnicos não são considerados como grupos porque possuem uma cultura comum, mas sim devido às diferenças culturais. Nas palavras do autor:

[...] a etnicidade representa a organização social de diferenças culturais [...]. Pensar a etnicidade em relaçáo a um grupo e sua cultura é como tentar bater palmas com uma mâo só. O contraste entre 'nós' e os 'outros' está inscrito na organizaçáo da etnicidade: uma alteridade dos demais que está explicitamente relacionada à asserção de diferenças culturais (BARTH, 2005, p. 16).

Ao enfocar a etnicidade, Barth (2011) se dedica aos aspectos generativos e processuais dos grupos, pois pressupóe o contato cultural e a mobilidade das pessoas. Ao considerar o grupo étnico do ponto de vista da atribuição de categorias de "nós" e "eles", o autor aborda a etnicidade como um processo organizacional que não pode ser distinguido, a priori e por definiçáo, de outras formas de identidade coletiva.

Assim, pertencer a uma categoria étnica demanda ser "um certo tipo de pessoa", pois os atores podem utilizar alguns traços culturais como sinais e emblemas de diferenças, ignorar outros, indicando seu pertencimento à cultura do grupo por meio das fronteiras, ou melhor, critérios de pertença. Desse modo, definem-se sinais ou signos manifestos, que são "[...] sinais diacríticos que as pessoas procuram e exibem para demonstrar sua identidade, tais como o vestuário, a língua, a moradia, ou o estilo de vida" (BARTH, 2011, p. 194).

As consideraçóes de Barth (2011), nos levam a pressupor que as fronteiras não fecham ou isolam os grupos, ao contrário, suas construções e manutenções representam jogos de interesse, negociados de acordo com suas necessidades. Tendo em vista os diferentes contextos históricos nos quais os grupos se inserem, estes podem criar categorias de autoatribuição e identificação que permitem suas distinçóes étnicas, delineando, assim, o que querem que os defina ou não. Nesse sentido, apesar dos fluxos e contatos, as fronteiras permanecem, na medida em que esses grupos as criam e recriam.

Caminhar em direção às fronteiras, transitar entre elas e/ou atravessá-las abrange tanto as demandas sociopolíticas dos grupos étnicos minoritários quanto a emergência de novas identidades e reinvençôes da etnia. Assim, interessa-nos saber que significados os ciganos têm atribuído à escola no contexto de sua vida atual, pois compreendemos, como Barth (2011), que os grupos étnicos estão em processo de interação social permanente, de modo que não é o isolamento que explica seus elementos definidores e sim o modo como os próprios membros escolhem autoatribuiçóes, negociando significados de acordo com seus interesses, 
diante do contato interétnico. Adotando a ideia de que as fronteiras não isolam os grupos étnicos, este estudo apoia-se na visão dinâmica da relaçáo entre os ciganos e a escola, ora podendo manter, ora excluir alguns traços culturais, sempre na rica condição do conhecimento mútuo.

\section{Educação, escola e cultura cigana}

Segundo Brandão (1993), a educação existe em cada povo, difusa em todos os espaços sociais, inserida na vida cotidiana, podendo existir de modo livre, ser transmitida, de forma oral, dos mais velhos aos mais novos; ou ser sistematizada, hierarquizada, pelo ensino formal, perpassada pelos conhecimentos da pedagogia. $\mathrm{O}$ autor aponta, ainda, que a educação existe "[...] entre povos que submetem e dominam outros povos, usando a educação como um recurso a mais de sua dominância” (BRANDÃO, 1993, p. 7). Essa dominação configura uma educação escolar marcada por ambiguidades e processos de exclusão.

Discutindo sobre a educação escolar em uma sociedade dividida em classes, Bourdieu e Passeron (1996) discorrem sobre a teoria da reproduçáo, segundo a qual o sistema educacional reproduz as desigualdades sociais, por meio de práticas que reforçam as relaçóes de dominação. Assim, de forma a manter seus privilégios e poder, os grupos dominantes buscam submeter os grupos dominados aos seus interesses de classe por meio de diferentes estratégias e em distintos espaços sociais. Nesse contexto, a escola é uma instituição que serve especialmente aos seus interesses pela possibilidade de inculcação ideológica que a perpassa. Para os autores, a escola possui uma "autonomia relativa", o que, em última instância, contribui para a perpetuação das relações de classe.

Dessa forma, os interesses e necessidades dos grupos dominados são relegados a constantes processos de violência simbólica. $\mathrm{Na}$ escola, seus saberes e conhecimentos não são reconhecidos nem valorizados e a eles são impostos valores e modos de conceber o mundo que atendem às demandas dos grupos dominantes. Alguns dos estudos sobre escolarização de ciganos a que tivemos acesso (FERRARI, 2010; BAREICHA, 2013), reafirmam essas constataçóes. Descendentes de povos de cultura ágrafa e pouco escolarizados ou analfabetos, quando inseridos em uma cultura letrada, suas possibilidades de se distanciarem dos processos de dominaçáo dos quais fala Brandão são ainda mais restritas.

Ao discorrer sobre a escola, Bourdieu (2007) a situa como campo do saber sistematizado, hierarquizado, metodologicamente estruturado. O campo é definido por ele como um espaço simbólico. As relaçóes sociais que nela se estabelecem organizam-se a partir de modos historicamente constituídos de relação entre grupos de diferentes estratos sociais, marcados por interesses distintos e por vezes 
opostos. Disso decorre a coexistência de uma variedade de sistemas de pensamento nesse espaço, nesse campo, o que gera para a escola a conflitante exigência de uma adaptação dos indivíduos ao sistema ofertado, com toda a sua diversidade.

Tendo como base o sistema de ensino francês, Bourdieu (2007) analisa como as categorias de pensamento das quais dispomos são influenciadas e/ou constituídas pelo trabalho desenvolvido na escola a partir das práticas que a estruturam. Para o autor, os sistemas de pensamento são aqueles pautados nos esquemas cognitivos dos indivíduos e os sistemas de ensino são as formas objetivamente estruturadas de transmissão do conhecimento.

Ao discorrer sobre o papel social da instituição escolar, Bourdieu (2007) problematiza não somente os efeitos sociais e políticos dos sistemas de ensino, mas também os cognitivos, ou seja, a forma como as categorias de pensamento que os indivíduos de diferentes grupos sociais dispóem são incorporadas, ou não, pela instituição escolar. Assim, um problema decorrente das "formas únicas" de ensino - características da escola - é o fato de que, além de os indivíduos não escolarizados náo terem seus esquemas de pensamento favorecidos pelos métodos de ensino padronizados, a maioria dos sujeitos que frequenta a escola acaba por internalizar esse modo único de pensar, visto que o formato padronizado é transmitido de maneira quase imperceptível.

Daí a importância da observação da distância entre os sistemas de ensino e os sistemas de pensamento, para que se possa refletir acerca dos efeitos da escolarização, tanto nos indivíduos que frequentam a instituiçáo escolar quanto em seus egressos, dado que existem inúmeras maneiras de pensar, agir, educar e ensinar. Muitas vezes, as abordagens restritas e homogeneizantes das formas de ensino oferecidas pela escola não fazem sentido para aqueles que não foram educados com base no sistema apresentado, como no caso dos ciganos, sujeitos historicamente afastados dessa instituição.

\section{O que a escola significa para os ciganos do Acampamento Sol?}

Diante das mudanças no contexto social e geográfico e suas consequências sobre os hábitos, objetivos, modos de viver e se relacionar dos ciganos, temos o cenário no qual podemos situar o modo como os ciganos adultos do Acampamento Sol estão sendo afetados pelas transformaçóes em curso. Por um lado, as demandas advindas do contexto de vida moderna e os problemas que este lhes apresenta, como pertencentes a um grupo étnico minoritário; por outro, um líder - Sr. Valdir - que, guardiáo das memórias, dos costumes e tradiçóes do grupo, medeia as nuanças desse processo com as várias reinvençóes e as múltiplas formas de lidar com o novo. 
Ao notar que seus filhos e noras estavam expressando o desejo de estudar, o Sr. Valdir não se opôs. Sempre que confrontado por outros ciganos, ou não ciganos, sobre essa questão, apresentava uma explicação para sua conduta de aceitação. Assim como recorria aos símbolos para explicar a casa de alvenaria "que não era casa" e sim um "rancho cigano", embora com um formato exterior de "casa não cigana", criava sentidos para a ida de seus familiares para a escola. Entretanto, essa visão não era compartilhada por todos os membros do grupo familiar. Os enunciados do Sr. Valdir e de seu filho João, os quais discutiremos a seguir, são representativos de dois modos distintos e extremos de compreender o lugar da escola em um contexto de mudanças significativas na vida desses ciganos.

\section{"A escola é o fim do cigano"}

Durante os nove anos de contato com os ciganos, com o gradual estreitamento dos laços e a consolidaçáo da confiança mútua, tanto o modo de nossa chegada quanto o tempo de permanência no acampamento foram se modificando. Assim, ao chegar ao acampamento, às vezes sentávamos nas cadeiras embaixo da árvore, próximo à barraca de Dona Lena, esposa de Sr. Valdir; outras, íamos à barraca de uma de suas noras, Luciana, Maria ou Laísa. Os homens, vez ou outra, chegavam, sentavam, participavam da nossa conversa.

Foi em uma dessas ocasióes que pudemos conhecer o que João pensava sobre a escola. "A escola é a morte do cigano", falou em tom áspero. Escutava nosso assunto quando a fala do seu irmáo Raul, muito entusiasmado com a possibilidade de estudar, o incomodou. Começaram uma discussão acirrada. João, filho mais velho do Sr. Valdir, repetia o discurso que, segundo ele, sempre escutara desde criança: "Escola, igreja e loja não são lugares para cigano". Conforme relembrava, crescera ouvindo o pai afirmar que nesses lugares "cigano era enxotado que nem se fosse um bicho".

O posicionamento de João era firmemente oposto ao dos demais que, mesmo apontando receios, desejavam frequentar a escola, estudar. João é o filho mais velho, casado com uma náo cigana. Pai de três filhos, dois deles, os mais novos, vão à escola. Em 2015, Rodrigo, seu primogênito, estava para concluir o ensino fundamental. Em várias ocasióes, Maria, sua esposa, discretamente viera me perguntar sobre as possibilidades para que o menino continuasse os estudos. Passava-lhe as informaçóes e constantemente auxiliava esclarecendo algumas dúvidas e possíveis direcionamentos sobre locais que poderia procurar para outras informaçôes. Desejava que o filho "um dia fosse para a Escola Técnica" e várias vezes me abordou com esse assunto.

Em 2016, após as férias, soubemos que Rodrigo cessara os estudos. Maria 
nos informou que já estava desgastada de tentar convencer o marido sobre a importância da escola para seu filho. Certo dia perguntamos a João se ele desejava estudar:

Deus que me livre! Já sofri demais nessa vida, moça! Vou procurar mais sarna pra se coçar? Vô nada! Você vê aí, os minino aqui: primeiro os pessoal lá da prefeitura conversou, conversou com nóis, negócio de Bolsa-Família, coisa e tal, nóis coloquemo os minino, tá bom! Daí eu pergunto pra senhora, pra quê?? Cigano vai fazer o que na escola? Ah, vai aprendê a lê, escrever, essas coisas... Eu nunca que aprendi nada e tô vivo até hoje, num tô? Eu acho assim, cada um tem seu jeito de pensá, pensa como quiser, mas, no meu conhecimento, cigano é da vida, não precisa de escola pra nada. Os minino antes casava tudo direitim, trabaiava que nem nóis, agora inventa aí de ter vergonha de nóis, de num querê trazê ninguém aqui... Se bem que escondê cigano é meio difícil, né dona? Mas pra mim, cê nem precisa perguntar mais nada disso, não, que minha opiniáo é essa: não tenho nenhuma vontade de estudar, pra mim a escola é o fim do cigano, vai pra lá, volta com a cabeça cheia das ideia contrária. Eu sempre vivi assim. Assim tá bom pra mim (JOÁO, Caderno de campo, 3 de setembro de 2016).

A partir desse momento, Maria passou a se aproximar mais para falar de si mesma, além do filho. Contou-nos que estudou até a quarta série do ensino fundamental, que sabe ler, mas muito mal. Com as novas tecnologias dos aparelhos de comunicação e a possibilidade de uso das redes sociais, desejava muito continuar os estudos, assim poderia "escrever certo e passar menos vergonha". Diz que seu filho sempre a repreendia, dizendo que escrevia "tudo errado", porém expressou preocupação, pois tinha certeza de que João não permitiria que ela frequentasse a escola:

Num tem aquele dia que nóis tava ali, dentro da barraca da Luciana, falando que nóis, as muié, tudo aqui quer estudá? Então, eu falei com ele que as menina aqui tava tudo querendo estudar. Pra que eu fui falá, Kátia?! Ele falô: 'Você não vai, não. Quero saber disso, não!'. Mas eu sei porque ele fica assim nervoso com esse negócio de celular, é que nóis tem a ciganada toda nos contatos. Aí tem festa, as ciganas solteiras, separadas, manda foto dos rapaiz. Outro dia a Zarina botô uma foto do rapaiz que ela tá gostando, dele mais ela no contato dela. O João viu 
e falô que eu tava conversando com homi na internet. Eu fui, mostrei pra ele a conversa, que era com a Zarina que eu tava falando, mas ele náo sabe lê, num acreditô, e também num qué aprendê, aí ele pegô meu telefone e jogou longe! Então, ele tem medo disso também, porque ele num sabe lê, ele fica com ciúme! (MARIA, Caderno de campo, 15 de fevereiro de 2017).

Para João, a escola significa uma ameaça. Compreende-a como um anúncio do "fim" dos ciganos". Por ter vivido seus 37 anos sem saber ler e escrever, acredita que não precisa de estudo. Também se sente inseguro em relação ao conhecimento que a esposa possui, ainda que restrito. $\mathrm{Na}$ opinião de Maria, impedindo-a de frequentar a escola e continuar os estudos, ela ficará limitada no uso do aparelho celular, o que para o marido é mais conveniente. A atitude de não aceitação da imposição do esposo elucida alguns dos significados da educação escolar para ambos. Para ela, um avanço; para ele, uma ameaça.

De acordo com Barth (2011, p. 199), quanto maiores as diferenças valorativas na interação de indivíduos com distinçóes étnicas, maiores as implicações de restriçóes sobre os papéis de atuação, uma vez que "[...] os indivíduos relutariam em agir de novas maneiras, com medo de que estes novos comportamentos pudessem ser inadequados a uma pessoa com sua identidade” . É nesse sentido que localizamos a postura de Joâo em relação à instituição escolar, dado que, em sua visão, sendo cigano, ele não pertence a alguns espaços, como "escola, igreja e loja". Em decorrência, Maria, sua esposa, também não pertenceria a esses lugares.

Os enunciados de João indicam que, até aquele momento, para ele, as fronteiras que separam ciganos e não ciganos estão rigidamente delimitadas, provocando tensôes resultantes do confronto entre os significados que atribui a si e a sua família como ciganos e as demandas e possibilidades de relaçóes e de existência que surgem no contato interétnico. Nas andanças características de sua vida nômade, a educação que recebeu de seus pais, aliada às próprias vivências, foi lhe impregnando de valores e modos de compreender o que é ser cigano em uma certa contraposição ao universo dos gajés. Em seus enunciados, os gajés surgem como os responsáveis pelo processo de desmantelamento de valores e costumes que parecem estar no núcleo dos componentes de sua autoatribuição como cigano, como os modos de trabalho do grupo e os casamentos definidos pelos pais. Diante dos elementos que aprendeu a utilizar para atribuir a si a categoria cigano (BARTH, 1989), João parece não ver possibilidades de ressignificação de costumes, o que provavelmente se acirra com o fato de muitos jovens sentirem vergonha de ser ciganos. 
Nesse contexto, a escola definida por João como uma ameaça, como um prenúncio do fim dos ciganos, parece ser sustentada por uma ideia que perpassou sua vida desde criança e que compóe seus critérios de autoatribuição: existem certos lugares que são para certos tipos de pessoas; escola, igreja e loja não são lugares para ciganos. Em sua visão, a escola não é um espaço para todos. Ele não a concebe como um local de acolhimento, ao contrário, suspeita que, se nela entrar, todas as bases que constituíram seus alicerces de vida serão rejeitadas, o que o coloca em uma posição de defesa em relação a ela. Para ele, a escola representa a morte simbólica de todo o saber que possui, das fundamentaçóes que alicerçaram sua identidade e pertencimento étnico. E por que temos uma escola que causa tamanha intimidação?

Bourdieu e Passeron (1996) e Bourdieu (2007) nos auxiliam nessa reflexão ao abordarem a autonomia relativa da escola na sociedade dividida em classes e sua função de reprodução da estrutura dessas relaçóes de classe, por meio da transmissão de valores e formas de pensar, agir e sentir típicas dos grupos dominantes para todos aqueles que nela ingressam. Nesse contexto, estudos realizados por Souza (2001) e Ferrari (2010) indicam que as concepçóes de mundo, vivências e valores dos grupos ciganos se chocam com os padróes estabelecidos pela escola. Desde as categorias de pensamento e os recursos cognitivos aos significados atribuídos ao conteúdo escolar, as diferenças, a desvalorizaçáo da cultura cigana e o preconceito ressaltam na relaçáo entre não ciganos e ciganos na escola, especialmente os mais pobres.

Nesse sentido, grande parte do que João aprendeu a valorizar, respeitar e almejar, como cigano, de modo geral não é reconhecido pela escola - e, para ele, pode se desmantelar com a escolarização: a cultura dos povos ciganos é tradicionalmente ágrafa, de transmissão oral do saber; a subsistência ocorre primordialmente por meio do escambo, permutas e trocas, distanciando-se enormemente do modo de produção e relações de trabalho típicas de uma formação social capitalista; há uma centralidade na família, como núcleo social, com relaçoos próprias entre seus membros; a honra e a "palavra dada" têm força de lei para o cigano. Então, como desejar ingressar na escola - esse espaço tão nefasto para ele?

Vemos assim o drama que se configura para João diante da principal forma de contato com os não ciganos - a escola, que é obrigatória para seus filhos e almejada por sua esposa. Para além dos desafios que se colocam a todos aqueles que nela adentram, em relação à resistência à inculcação ideológica de concepçóes de mundo dos grupos dominantes (BORDIEU; PASSERON, 1996), João vê, ainda, a escola como uma ameaça ao modo de ser cigano. De maneira diferente, veremos a seguir, que seu pai, o Sr. Valdir, busca uma ressignificação do modo de ver o cigano e a escola em um mundo em transformação para eles. 


\section{"A escola é uma luz no caminho do cigano"}

Devido ao fato de o Sr. Valdir ter mais idade e, aparentemente, menos proximidade com as mudanças em curso, podemos considerar que ele teria um posicionamento mais entrelaçado às tradiçóes e resistente às transformaçóes. Porém, a partir de meados de 2016, em várias ocasióes, seus enunciados indicaram que era ele quem estava determinando para o grupo algumas reelaboraçôes acerca dos significados da escola.

Certo dia estávamos sentadas com Dona Lena e o Sr. Valdir em frente à sua barraca. Falávamos sobre o tempo, sobre o fim do casamento de uma sobrinha e outros temas. Naquela semana, haviam chegado uns parentes de Minas Gerais. Montaram a barraca nos fundos do terreno. De acordo com Seu Valdir, vieram ficar uns tempos, porque lá estava difícil demais para eles.

Durante a conversa, o Sr. Nilo, o primo do Sr. Valdir, veio até onde estávamos. Usava uma bengala para se apoiar, vestia uma bermuda jeans, sem camisa, alguns cordóes pendurados no pescoço. Mancava da perna direita e se equilibrava com dificuldades. Fomos apresentadas a ele como aquelas que mexem "com essas coisas aí de escola". Ficamos por algum tempo conversando sobre as dificuldades encontradas pelos ciganos em relação à escola. Perguntamos se ele tinha vontade de estudar. Ele acha graça do questionamento e responde: "Eu num tenho mais cabeça funcionando pra isso, sô ruim de aprender, num enxergo direito, tinha que tê sido quando eu era criança pequena, mas se hoje tá assim, difícil pra nóis, a senhora imagina naqueles tempo".

O Sr. Valdir, que até então acompanhava a conversa só escutando, intervém. Diz que a idade pode dificultar, mas pensa que, caso a pessoa tenha o desejo e o direito, nada pode ser empecilho. Perguntamos o que ele acha de seus filhos e suas respectivas esposas irem à escola:

Nosso Deus, acho bom demais! Se acontecesse deles podê ir mesmo, eu ia achá é muito bom. Meus netos vão tudo, eu faço questá! Cigano tem que evoluir, as coisas mudaram muito, os tempos de hoje, Nilo, é muito diferente do nosso. Eu deixo minha muié, meus filhos, minha nora, meu neto, minha neta. Vai tudo pra escola. Eu memo só num vou pruque tô velho demais, daqui a pouco tô morrendo mesmo. Mas eu tenho fé que a vida deis vai cê mais fácil que a nossa. Espia hoje, cada barraca aqui tem uma televisão de cor, geladeira. O Fernadim ali embaixo tem até esse tal de computador. Então se não saí pra aprendê as coisas, fica pra trás (Seu VALDIR, Caderno de campo, 14 de fevereiro de 2016). 
Surpreendemo-nos com a fala de Sr. Valdir. Contrariamente ao seu filho João, pensa que a escola é necessária para a evolução dos ciganos em consonância com as demandas do mundo moderno. Seus longos anos de lida na aridez das estradas permitem-lhe identificar elementos que são importantes para a subsistência de seus descendentes no novo contexto, entre eles, a escola, como meio de tornar a vida mais fácil.

Por outro lado, seu posicionamento parece indicar uma visão de uma escola mais idealizada por ele do que talvez real. Embora sua fala não especifique o que ele acha que deve ser aprendido na escola, ou seja, não se refere aos conteúdos em si, sua interpretação do espaço escolar não necessariamente condiz com a escola real - uma escola que, de modo geral, serve ao modelo capitalista de produção, que dissemina valores e modos de pensar e de sentir próprios dos grupos dominantes, provocando muitas tensóes e exclusóes daqueles que não se encaixam nos padróes estabelecidos por ela (BOURDIEU; PASSERON, 1996).

Essa escola idealizada pelo Sr. Valdir nos leva a situar as demandas atuais dos ciganos do Acampamento Sol a partir de uma perspectiva que se alinha com aquela da escola unitária, ainda utópica, defendida por Gramsci (1979): aquela que promove uma formação humanística de cultura geral e que, ao mesmo tempo, prepara as novas geraçóes das classes menos favorecidas para a superação da condição subalterna na qual se encontram. Uma escola que traz à tona a necessidade de movimentos contra-hegemônicos, ou seja, que levem as classes dominadas a superar a dominação da classe econômica favorecida. Uma escola que promove conhecimento, criticidade e mecanismos que instrumentalizem aos desfavorecidos meios apropriados para suas lutas em favor de um projeto de emancipação social.

Para o autor, existe um salto enorme entre a escola propriamente dita e a vida, entre o ensino quase puramente dogmático e os processos criadores e autônomos. Enquanto a escola reproduzir, em suas práticas, as desigualdades sociais, mais distante fica a escola unitária descrita por Gramsci (1979), que prepare de maneira equitativa todos os alunos. Assim, a "evoluçáa" dos ciganos por meio da escola, como apregoada pelo Sr. Valdir, possivelmente se apresente mais como um desejo do que como um anúncio de um projeto a se realizar.

Para o velho cigano, as ressignificaçóes que ele faz da instituição perpassam as durezas que já enfrentou e os anseios de um futuro melhor que o seu para seus descendentes. As fragilidades físicas advindas da idade avançada, os adoecimentos e a precariedade refletida na ausência de conforto no momento da velhice fazem com que o Sr. Valdir deseje outro modo de vida para os netos:

Ocê, olha aqui meu rosto, todo enrugado, parece que eu tô pra lá de cem anos de vida num é mesmo? Muita luta nessa 
vida, minha filha, meus menino sofrero muito junto de nós, carroça pra cima, carroça pra baixo, polícia entrando barraca pra dentro, puxando eu, eles pegando no choro, com medo. Agora, meus neto já têm carro, televisão, vão pra escola. Esses num sabe o que é sofrimento. Por isso que, quando a senhora pergunta eu se eles pode ir pra escola, eu digo que sim. Eles num vai deixar de ser cigano, não. Pra mim, que já tô veio, tem mais jeito não, mais pra eles, tem! Tinha o lado bom, que eles num conheceram. Num existia tanta violência que nem hoje. A gente podia andar pelo mundo sem perigo, né minha filha? Era bom, a chuva fina batendo na lona pra gente dormir, era bom demais (Seu VALDIR, Caderno de campo, 27 de outubro de 2015).

Em determinado momento, perguntamos sobre Dandara, sua neta de cinco anos. Ela não gosta de usar "roupas de cigana”. Quando pede à mãe para não usar, no entendimento de sua avó, está dando sinais de vergonha do seu grupo de pertencimento. O Sr. Valdir responde:

Tem que ver também que a Dandara já nasceu aqui, no bairro, vendo as menina aí tudo com bermuda, calça comprida. Ela vai na escola, e lá só tem ela e a Isabelle que são cigana. Então, se for só as duas vestidas de cigana, fica sem jeito pra elas, né? E a Dandara não gosta de vestidinho de cigana. Você já viu, né? A mãe dela manda fazer cada um táo bonitinho para ela, e ela num gosta, fica pedindo pra tirar e chora. Aí eu falo: 'Deixa ela ir assim mesmo, faz a menina chorar, não!'. Mas no dia que tem festa de cigano, aí tem que ir de vestido! Aí não pode ser de outro jeito, né? Porque ela precisa conhecer a tradição do povo dela, sabê respeitá. Ela é criança ainda, então algumas coisas tem que ensinar para ela, pra não perder, né? (Seu VALDIR, Caderno de campo,14 de fevereiro de 2016).

A visão do Sr. Valdir nos aponta um dos modos de organizar a interação entre os ciganos e a escola. As regras que demarcam a liberação ou não do uso do vestido cigano indicam a não passividade do grupo diante de suas novas demandas sociais. A primeira vez que soubemos da posição do Sr. Valdir, a respeito do tema, foi quando Luciana engravidou de Dandara. Segundo narrou Dona Lena, ele ficou tão feliz, mas tão feliz por ter uma neta "menina muié”, que disse para Luciana que até a deixaria vesti-la de "calça jeans", se assim desejasse.

Ao determinar quando as mulheres (e também sua neta) devem/podem ou não usar as vestimentas ciganas, o Sr. Valdir expressa as escolhas que faz para 
atribuir a categoria "cigano" (BARTH, 1989). Em sua concepção, sua neta pode usar calças e ir à escola que continuará sendo cigana. $\mathrm{O}$ fim do cigano não está vinculado às mudanças no tipo de vestimenta, mas à impregnaçáo de valores da cultura cigana. Reconhece que, para continuarem recebendo o benefício BolsaFamília, a neta precisa estar matriculada e frequentando a instituição. Assim, ressignifica o modo de vestir e os impactos deste na construçáo da identidade cigana da menina.

Nesse panorama, a ida dos ciganos para a escola pode gerar tensóes, mas também a possibilidade de permeabilidade das fronteiras que separam ciganos e não ciganos. Uma visão mais flexível em relação às fronteiras e à autoatribuição, como as apontadas nos enunciados do Sr. Valdir, abre espaço para certa potencializaçáo do encontro interétnico na escola. Como bons negociantes, os ciganos tendem a questionar, deslocar, provocar. Dessa tensão e de suas possíveis crises, dois movimentos nos parecem promissores para ciganos e não ciganos: a transformaçáo, apoiada nas mudanças que as crises provocam; e a emancipação dos sujeitos, ciganos ou não ciganos, via aquisição do conhecimento mútuo.

Diante disso, talvez seja possível olhar a escola para além de uma perspectiva reprodutivista, que perpassa os estudos de Bourdieu e Passeron (1996), na qual o encontro interétnico possa possibilitar algumas fissuras na dureza das práticas que segregam e excluem aqueles que se distanciam ou que resistem à incorporação dos modos de pensar e de viver dos grupos dominantes.

A habilidade de negociante do Sr. Valdir fica evidente em trechos de uma conversa, na qual lhe perguntamos sobre a permissão para suas noras frequentarem a escola: "Como deveriam se vestir: sendo não ciganas, poderiam ir de uniforme ou calça/bermuda ou, por serem esposas de ciganos, deveriam ir com os vestidos típicos do grupo?". Ele responde que "Podem ir como quiserem, como se sentirem mais à vontade, porque tem vezes que as pessoas trata mal elas por causa da roupa de cigana". Questionado sobre se a escolha de irem de calças ou uniforme não levaria a dúvida por partes dos outros alunos sobre elas serem ou não ciganas, o cigano é enfático: "Piriga não, minha filha, cigano tem a postura dele. Elas num nasceram cigana, mas casaro com cigano, vive junto de nóis, intão elas já pegaro nosso jeito. Num é a roupa que faz a cigana, é o jeito dela, a postura dela, de respeito".

Os enunciados do Sr. Valdir nos indicam que o cigano elege o que o define. Suas palavras nos permitem compreender que "ir para a escola" é uma opção para os adultos ciganos do seu grupo, e que tal fato não faz com que estes "deixem de ser ciganos". Considerando-se o simbolismo envolvido, temos que "o jeito cigano de ser" faz com que as mulheres se identifiquem e sejam identificadas como tais. Sua permissão para que elas estudem perpassa 
o compromisso com a conduta que deve ser adotada pelas mulheres quando fora do Acampamento Sol e dentro da instituição escolar, uma vez que o poder simbólico é que confere sentido às ações sociais, por se tratar de "[...] um poder de construção da realidade que tende a estabelecer uma ordem gnoseológica: o sentido imediato do mundo" (BOURDIEU, 1989, p. 9). Nesses termos, para ele, a escola não é vista como ameaça, pois ressignificadas as ações e os comportamentos, é tida como um outro espaço social qualquer, que suprirá as demandas de aprendizado do grupo sem impactar as identidades, pois eles são os responsáveis por defini-las.

Certa vez, estávamos almoçando na casa de Luciana. Falávamos sobre o desejo nutrido por Luciana e por Raul de estudar. Entre todos os adultos do grupo, eram os mais motivados. Luciana diz que, se pudesse frequentar a escola, iria "vestida de cigana, porque é sinal de respeito com o marido". Perguntamos ao Sr. Valdir se ela poderia ir de uniforme, se a escola exigisse, ou com calça comprida:

Pode, sim, minha filha, o que faz o cigano né a roupa, não. Se você chegasse aqui toda vestida de cigana, com saia rodada, brinco, pulseira, anel, cordão e me falasse assim: 'Oia aqui, veio, a moça cigana!'. Eu oiava dentro dos seus oio e falava: 'Né cigana, não'. Agora você coloca um cigano na minha frente, aqui, oh! Pode tá pelado, eu sei que é cigano! Nóis sabe quem é cigano. A roupa quer dizer nada não! Ela mesma, num é cigana, né? Mas casô com meu filho, se veste de cigana, vive aqui, junto de nóis tem muitos anos já, mas cigana, cigana mesmo ela num é, né? Já a Dandara, se vestir de cigana ou não, num faz diferença, porque ela é cigana (Seu VALDIR, Caderno de campo, 12 de julho de 2016).

O Sr. Valdir, como podemos perceber, é quem organiza as açôes do grupo, orientando os comportamentos conforme define o que considera importante para a manutenção do seu modo de vida:

O autor, mesmo quando só diz com autoridade aquilo que é, mesmo quando se limita a enunciar o ser, produz uma mudança no ser: ao dizer as coisas com autoridade, quer dizer, à vista de todos, e em nome de todos, publicamente e oficialmente, ele subtrai-as ao arbitrário, sanciona-as, santifica-as, consagra-as, fazendo-as existir como dignas de existir, conforme a natureza das coisas 'naturais' (BOURDIEU, 1989, p. 114). 
Nesse andejar pelos caminhos da vida, o Sr. Valdir produz significados e, produzindo-os, faz mudanças, vive as transformaçóes e as consagra em seus enunciados e posicionamentos. Organiza a vida social de acordo com as demandas do seu grupo, cria e recria, exclui e incorpora, usa sua autoridade de líder do grupo para enunciar e anunciar quem são, quais são suas crenças, desejos, valores, limites, possibilidades. Nesse processo, lembra-nos do sentido não limitador do surgimento da palavra fronteira.

Do posicionamento e atitudes do Sr. Valdir, que liga os fios das crenças, costumes e valores às construçóes simbólicas, emergem novos significados compartilhados publicamente a partir de um conjunto de símbolos escolhidos por seu grupo. Tecer esses fios requer do velho cigano uma postura de ajustes: ora de flexibilização, ora de manutenção das fronteiras. Amarrar os fios, construir as teias, criar e recriar fazem com que ele assuma a posição de negociador que sempre lhe coube na relação entre o mundo cigano e o náo cigano ou, como afirma, entre eles e a "sociedade", entre eles e os "brasileiros".

Se recentemente a escola passou a ser uma possibilidade - e uma obrigação para seus filhos, levando à necessidade de ressignificaçóes acerca de sua educação, no caso dos adultos ciganos, os depoimentos indicam que a possível ida à escola implica - e é parte - novas aberturas nas zonas fronteiriças.

\section{Considerações finais}

No Acampamento Sol, a maioria dos ciganos adultos manifesta o desejo de ir à escola, por entender que ela pode suprir demandas colocadas especialmente com a fixação. A sedentarização, a regularização de documentos básicos, como certidão de nascimento e de identidade, e o fornecimento de um endereço fixo propiciaram a formação de vínculos com o entorno, desencadeando novas relaçóes com os moradores locais, agora mais prolongadas e menos fortuitas. Com a ida dos filhos para a escola, as ressignificaçóes começaram a emergir e essa instituição começou a fazer parte da vida dos sujeitos desta pesquisa.

Tais ressignificações estão ocasionando a incorporação da escola às suas rotinas de vida, já que, ao deixarem o modo nômade, frequentá-la se tornou uma possibilidade. Não mais viajantes, passam a se configurar de novas formas e, consequentemente, a ter condiçóes de sustentar algumas obrigatoriedades da instituição escolar, como horário para entrada e saída, frequência regular, endereço fixo, uso de uniforme padronizado, entre outras.

No entanto, essas ressignificaçóes não ocorrem sem tensão, o que pode ser demonstrado principalmente pelos diferentes posicionamentos do Sr. Valdir e de seu filho João a respeito da escola. 
Mais inflexível à mudança, à permeabilidade das fronteiras e a ressignificaçóes do modo de vida cigano, diante da fixação e do estreitamento do contato interétnico, João resiste à escola por considerar que ela é o "fim dos ciganos". De fato, qualquer contato com o outro implica transformaçóes. Constituímo-nos na identidade e, também, na alteridade. Entretanto, em uma sociedade estruturada em classes, os modos de constituição, pessoal e coletivo, necessariamente se articulam com as relaçóes de poder instauradas entre essas classes. Náo escapando a essas relaçóes de poder, a escola também serve aos interesses de determinados grupos e não de outros. No jogo das relações, João se dá conta de que inexiste espaço para a cultura cigana na escola como está majoritariamente organizada. Também não vê possibilidades de ressignificações no âmbito da própria cultura para incorporar o novo contexto que se delineia.

Por outro lado, vemos o Sr. Valdir em um esforço de ressignificação de aspectos de sua cultura, de forma a incorporar esse novo contexto, sobretudo com a fixação. Busca uma forma de manter o núcleo de sua cultura, mesmo diante das demandas que se colocam com o estreitamento do contato interétnico. Quando nos diz que náo são as roupas nem o tipo de moradia que demonstram quem é ou náo cigano, está nos informando que, embora tenham construído paredes e verbalizado o desejo de frequentar a escola, são eles que definem quem pertence ao seu grupo étnico, ou seja, ele, como líder, é quem identifica seus pares. Parte significativa dos adultos, membros do grupo, dá coro a seus enunciados. Deles se apropriando, vão amarrando as teias dos significados tecidos e, assim, traçam os caminhos para as travessias das fronteiras em um ir e vir constante, em um contínuo processo de porosidade e manutenção das fronteiras.

Com essas ressignificaçóes, o grupo pode manter uma unidade cultural e étnica pautada em seus valores básicos e no legado dos seus conteúdos culturais, ao mesmo tempo em que mantém ou flexibiliza as fronteiras. Quando desejam marcar a pertença étnica, os ciganos exibem as tatuagens realçadas com os acessórios, investem na vestimenta típica, escolhem cores fortes para pintar os ranchos que, em tais ocasióes, chamam de barracas. Enfim, buscam elementos que os diferem para demarcar sua identidade. Ao contrário, quando em negociação para suprir suas necessidades atuais, eles flexibilizam as fronteiras étnicas e sociais, estabelecendo novos modos de relacionamento com o entorno, com a maioria não cigana, criando novos tipos de moradia, brechas para uso de roupas não habituais entre as mulheres, como calças e blusas, entre outros aspectos.

Nesse contexto, coloca-se a demanda da escola: obrigatoriedade para as crianças e jovens e desejo de estudar por parte de alguns adultos do grupo. Para o Sr. Valdir, a escola é "uma luz" para o cigano, uma vez que pode propiciar sua "evolução" e uma "vida mais fácil”. Diferentemente de seu filho Joáo, o Sr. Valdir 
tem uma visão otimista da escola. Em seus enunciados, não emerge a perspectiva excludente e disseminadora de valores dos grupos dominantes que perpassa a escola: visão ingênua ou utópica da escola? Talvez nem uma nem outra. Talvez a esperança de um velho cigano em dias melhores para seus descendentes, longe dos sobressaltos durante a noite, com polícia entrando na barraca e prendendo adultos em meio ao medo e choro das crianças. Longe da dor de ter doado a própria filha quando criança por não ter condiçóes de cuidar dela ou da falta de perspectivas para seus filhos e netos.

\section{Referências}

BAREICHA, L. C. F. Educaçáo e exclusáo social: a perspectiva dos ciganos e dos não ciganos. 2013. 378 f. Tese (Doutorado em Educação) - Programa de Pós-Graduação em Educação, Universidade de Brasília, Brasília, 2013. Disponível em: http://repositorio.unb.br/bitstream/10482/13520/1/2013_ LucianaCamaraFernandesBareicha.pdf. Acesso em: 3 mar 2019.

BARTH, F. Grupos étnicos e suas fronteiras. 2. ed. São Paulo: Ed. Unesp, 2011. 30, 2005.

Etnicidade e o conceito de cultura. Antropolítica, Niterói, n.10, p. 15-

BOURDIEU, P. O poder simbólico. Tradução de Fernando Tomaz. Rio de Janeiro: Bertrand Brasil, 1989.

. A economia das trocas simbólicas. São Paulo: Perspectiva, 2007.

BOURDIEU, P.; PASSERON, J. C. La reproducción: elementos para uma teoría del sistema de ensenãnza. 2. ed. México: Fontamara, 1996.

BRANDÁO, C. R. O que é educação. 28. ed. São Paulo: Brasiliense 1993. (Coleção Primeiros Passos).

BRASIL. Lei no 10.172, de 9 de janeiro de 2001. Estabelece o Plano Nacional de Educação. Diário Oficial da Uniáo, Brasília, DF, 10 jan. 2001. Disponível em: http://www.planalto.gov.br/ccivil_03/LEIS/LEIS_2001/L10172.htm. Acesso em: 4 mar. 2019.

. Lei no 13.005, de 25 de junho de 2014. Aprova o Plano Nacional de Educação e dá outras providências. Disponível em: http://www.planalto.gov.br/ ccivil_03/_Ato2011-2014/2014/Lei/L13005.htm. Acesso em: 3 mar. 2019.

CUCHE, D. A noção de cultura em ciências sociais. Bauru: Edusc, 1999. 
FERRARI, F. O mundo passa: uma etnografia dos Calons e suas relaçóes com os brasileiros. 2010. Tese (Doutorado em Educação) - Departamento de Antropologia Social, Universidade de São Paulo, São Paulo, 2010.

GEERTZ, C. A interpretaçáo das culturas. Rio de Janeiro: LTC, 2008.

GRAMSCI, A. Os intelectuais e a organizaçáo da cultura. 3. ed. Rio de Janeiro: Civilização Brasileira S. A., 1979.

MALINOWSKI, B. K. Argonautas do Pacífico: um relato do empreendimento e da aventura dos nativos nos arquipélagos da Nova Guiné melanésia. 3. ed. São Paulo: Abril Cultural, 1984.

MULLER, B. C. Os ciganos Calon do acampamento em Praia Grande e o espaço escolar: umolharetnomatemático. 2014.189f.Dissertação(MestradoemEducaçáo emCiênciaseMatemática)-ProgramadePós-Graduação emEducaçãoem Ciênciase Matemática, Instituto Federal do Espírito Santo, Vitória, 2014. Disponível em: http://educimat.ifes.edu.br/images/stories/Publica\%C3\%A7\%C3\%B5es/ Disserta\%C3\%A7\%C3\%B5es/2014_Beatriz_Cezar_Muller.pdf. Acesso em: 3 mar. 2019.

SOUSA, C. J. dos S. Um olhar (de um cigano) cúmplice. In: LIÉGEOIS, J.P. Que sorte, ciganos na nossa escola!. Lisboa: Secretariado Entreculturas, 2001. p. 33-52.

VELHO, G.; KUSCHNIR, K. (Org.). Pesquisas urbanas: desafios do trabalho antropológico. Rio de Janeiro: Jorge Zahar, 2003. 